\title{
Immunodetection of surfactant proteins in human organ of Corti, Eustachian tube and kidney ${ }^{\star}$
}

\author{
Orhan Kankavi ${ }^{\bowtie}$ \\ Therapeutics Research Group, Deptartment of Medicine, University of Queensland, Princess \\ Alexandra Hospital, Brisbane, QLD 4102, Australia
}

Received: 09 January, 2003; revised: 12 May, 2003; accepted: 31 July, 2003

Key words: organ of Corti, kidney, Eustachian tube, Western blotting

\begin{abstract}
The presence of surfactant proteins was investigated in the human organ of Corti, Eustachian tube and kidney tissues. It has previously been shown that lamellar bodies are present in hairy cells of organ of Corti, in the cytoplasm of secretory and lumen of tubal glands of Eustachian tube and kidney renal basement membrane. No evidence for the presence of surfactant proteins in the organ of Corti and kidney has been presented until now. The aim of this study was to find out if surfactant proteins were expressed in other epithelia such as organ of Corti, Eustachian tube and kidney. Surfactant proteins were identified using one-dimensional sodium dodecyl sulfate-polyacrylamide gel electrophoresis and Western blotting. On one-dimensional Western blots, bands for surfactant protein $A$ in human Eustachian tube (SP-A, $34 \mathrm{kDa}$ ) and in kidney extracts, and for surfactant protein D (SP-D, $43 \mathrm{kDa}$ ) in Eustachian tube and in kidney extracts (SP-D, $86 \mathrm{kDa}$ ), and for surfactant protein B (SP-B, $8 \mathrm{kDa}$ ) in human Eustachian tubeand organ of Corti extracts were detected. Bands corresponded to monomeric forms of lung surfactant proteins. These results indicate the presence of SP-A and SP-D in kidney epithelium, SP-A, SP-B and SP-D in Eustachian tube and SP-B in the organ of Corti.
\end{abstract}

Most research on surface tension and surfactant in biological systems has been carried out on the surface active material (surfactant) of the lungs. Other organs such as Eustachian tube (ET), organ of Corti and synovial membrane, etc. have lately been shown histologically and histochemically to contain elements similar to those found in the

\footnotetext{
The authors acknowledge financial support from the Princess Alexandra Hospital Research and Development Foundation.

${ }^{\bowtie}$ Address for correspondence and reprint requests should be addressed to: Dr. Orhan Kankavi, The University of Kafkas, Faculty of Veterinary Medicine, Department of Surgery, Kars 36100,Turkey; tel.: (90) 474223 2792; fax: (90) 474223 7958; e-mail: okankavi@hotmail.com
}

Abbreviations: SP-A, SP-B, SP-C, SP-D, surfactant proteins A, B, C, D; ET, Eustachian tube; BAL, bronchoalveolar lavage; TBS/Tris-buffered saline; PBS, phosphate-buffered saline. 
respiratory epithelium. Probably there are specialized cells or organelles such as lamellar bodies in the Eustachian tube, organ of Corti and kidney epithelium expressing and secreting surfactant proteins. The local surfactant system of these tissues is of major functional significance. The distribution of lamellar bodies is closely related to surfactant production at different body sites. The presence of surface-active material in the lung alveolus has been known for several decades as being essential for normal lung function; the material has four surfactant proteins as key components.

The cochlea and the vestibule are responsible for hearing and balance in the mammalian inner ear. The organ of Corti is a gelatinous mass shaped like a snail. It is enclosed in the cochlea, which is deeply embedded in the temporal bone. Harada and co-workers (1986) have suggested that lamellar bodies (Hencen body) are present at the upper part of the supranuclear region, consisting of dilated cisterna at the center of hairy cells. The ET is the natural connection between the ear and the nose and throat. The presence of surface tension lowering substances (surfactant material) is needed to ventilate the middle ear, being crucial for functioning of the organ. The presence of lamellar bodies in renal biopsies was described by Billis (1994), and Ormos (1995) suggested that glycoproteins and proteoglycans were constituents of the lamellar bodies within the kidney basement membrane.

At present four surfactant proteins have been identified and characterized in the lung: SP-A (King et al., 1973), SP-B (Glasser et al., 1987), SP-C (Warr et al., 1987) and SP-D (Lu et $a l ., 1992)$. SP-A and SP-D are members of a family of collagenous carbohydrate-binding proteins (collageneous C-type lectins), now generally called collectins because they contain collagen-like domains and carbohydrate recognition domains. Both these proteins recognize and interact with glycoconjugates on the surface of microorganisms including bacte- ria, viruses and allergens (Haagsman et al., 1990). The synthesis of SP-A and SP-D seems to be more widely expressed so that SP-A occurs in mucus-producing cells of the rat stomach, salivary, sweat, mammary and lacrymal glands as indicated by RT-PCR (Chailley-Heu et al., 1997). Also, the presence of SP-A in epithelial cells of the rat small and large intestine has been demonstrated by immunohistochemistry as well as by RT-PCR and cDNA cloning (Rubio et al., 1995). SP-B and SP-C are small hydrophobic proteins (Fisher et al., 1988; Vamvakopoulos et al., 1995). Both SP-B and SP-C significantly increase the ability of surfactant phospholipids to adsorb to the air-liquid interface (Taneva \& Keough, 2000). The secretion of SP-B is most important for sustaining the surface tension-lowering properties of pulmonary surfactant and to date it has been thought that SP-B and SP-C expression is confined to lung epithelium. The presence of SP-B and SP-C together with SP-A and SP-D has recently been shown in the various structures of the skin and its secretions (Roberts MS, Kankavi O, Mo Y-K, Kroon PN, Mellick GD, Saunders N, Masci PP, Cross SE, Whitehouse MW, Hills BA., unpublished data).

Paananen and co-workers (1999) have detected SP-A and SP-D expression in porcine ET and sequences from ET showed 100\% homology with the corresponding proteins in porcine lung as determined by RT-PCR and Northern hybridisation. Cellular and subcellular SP-B gene expression in the porcine Eustachian tube epithelium was also described (Paananen et al., 2001).

The aim of this study was to search for tissues which contain discrete compact lamellar material of regular periodicity similar or identical to structures present in the lung, known to contain surfactant. Whereas surfactant proteins have been studied in detail in the lung, nothing is known about the possible presence of surfactant-related proteins in organ of Corti as well as in kidney epithelium. The data outlined in this paper provide new evidence that human Eustachian tube express significant 
levels of SP-A, SP-B, SP-D and human organ of Corti SP-B and kidney SP-A and SP-D.

\section{MATERIALS AND METHODS}

\section{Preparation of Eustachian tube lavage.}

Human temporal bones were obtained from John Tonge Centre (Brisbane, Australia) Right petrostemporal bones with a diameter of approximately $8 \mathrm{~cm}$ with some bone fragments of surrounding structure were stored in $0.9 \% \mathrm{NaCl}$ solution at $-40^{\circ} \mathrm{C}$ until use. The extractions involved perfusing the middle ear and ET through the tympanic membrane in order to extract proteins at the air/tissue interface. ET was lavaged with PBS, $\mathrm{pH}$ 7.4, (about $1 \mathrm{ml}$ ) with a plastic syringe $3-5$ times. The lavage fluid was then spun in a low speed centrifuge to remove debris, followed by further centrifugation at $10000 \times \boldsymbol{g}$ for $2 \mathrm{~h}$ at $4^{\circ} \mathrm{C}$. The resulting pellet was collected and stored at $-20^{\circ} \mathrm{C}$ until it was used for one-dimensional electrophroseis and Western blotting.

\section{Preparation of organ of Corti lavage.} This procedure involved removal of the dura from bony fragments of the petrostemporal bone and using a dental burr to create an opening $(0.5 \mathrm{~mm})$ into the superior semicircular canal through which lavage with PBS, $\mathrm{pH}$ 7.4 (3-5 times, $1 \mathrm{ml}$ of buffer) was carried out. The lavage fluid was then treated as above.

Extraction of kidney tissue proteins. A crude mixture of proteins was extracted from human kidneys in TBS, $\mathrm{pH}$ 7.4, as follows. Kidney tissue were obtained from patients who have had rejection kidney transplantation at the Princess Alexandra Hospital, Brisbane (Australia). An aliquot of tissue (approx. $300 \mathrm{mg}$ ) was suspended in the buffer and homogenized $(3 \times 10 \mathrm{~s}$ bursts on ice $)$ with a Polytron homogeniser. The pellets were obtained using the same protocol as detailed above.
Preparation of human lung bronchoalveolar lavage (BAL). BAL (about $0.5 \mathrm{ml}$ ) was collected from patients having lung lavage at Princess Alexandra Hospital (Brisbane, Australia) and diluted to $20 \mathrm{ml}$ in $\mathrm{BN}$ buffer (0.01 M sodium borate, $\mathrm{pH}$ 7.4, $0.15 \mathrm{M}$ $\mathrm{NaCl}, 3 \mathrm{mM} \mathrm{CaCl} 2$ ). The lavage was centrifuged at $250 \times \mathrm{g}$ for $10 \mathrm{~min}$ at $4^{\circ} \mathrm{C}$ to remove cellular debris, the supernatant subsequently centrifuged at $27000 \times \mathrm{g}$ for $2 \mathrm{~h}$ at $4^{\circ} \mathrm{C}$, and the resulting pellet was resuspended in $100 \mu \mathrm{l}$ $\mathrm{BN}$ buffer and kept in $-20^{\circ} \mathrm{C}$ (Liau \& Ryan, 1991).

Antibodies. Monoclonal mouse antibody against human SP-A (21.0 mg/ml), was kindly provided by Dr. Noriaki Kinoshita (DAKO, Kyoto, Japan Co., Ltd). Polyclonal mouse antibody against human SP-B protein (PO-B $8 \mu \mathrm{g} / \mathrm{ml}$ ) was kindly provided by Dr. Terence E. Nicholas (Department of Human Physiology and Critical Care Medicine, School of Medicine, Flinders Medical Centre, Adelaide, Australia), a recombinant SP-D protein antibody (CHO SP-D, $190 \mu \mathrm{g} / \mathrm{ml}$ ) and polyclonal SP-D antibody (SP-D IgG, $1 \mathrm{mg} / \mathrm{ml}$ ) were kindly provided by Dr. Dennis R. Voelker (National Jewish Center, Denver, CO, U.S.A.). Anti-rabbit IgG-peroxidase conjugate (A-0545), anti-goat IgG-peroxidase conjugate (A-4174), goat anti-mouse IgG antiserum (M-8642, $2 \mathrm{mg} / \mathrm{ml}$ ) were purchased from Sigma Chemical Company (St. Louis, MO, U.S.A.).

SDS/PAGE and Western blotting. Gels were prepared in a Bio Rad Protean or MiniProtean electrophoresis apparatus. Samples containing $15-250 \mu \mathrm{g}$ of protein were subjected to one-dimensional SDS/PAGE (12\%, $15 \%$, mass $/ \mathrm{v}, 1.5 \mathrm{~mm}$-thick gel polyacrylamide gel) by the method of Laemmli (1970) with a Mini Protean II apparatus (Bio-Rad, California, U.S.A.) in the presence of $5 \%$ $\beta$-mercaptoethanol. Samples were added to the sample buffer (20 $\mu$ l total) and boiled at $95^{\circ} \mathrm{C}$ for $5 \mathrm{~min}$. After cooling they were added by pipette to each well containing running buffer and run for $1 \mathrm{~h}$ at room temperature 
set at constant voltage of 200 volts. After electrophoresis, gels were used in Western blotting of antigens by transferring separated proteins onto nitrocellulose membrane. Transfer was performed at $100 \mathrm{~V}, 350 \mathrm{~mA}$ for 1 h using model 200/2.0 power supply (Bio-Rad, California, U.S.A.). After blocking for $1 \mathrm{~h}$ with $5 \%$ (mass/vol.) nonfat milk (Diploma) in $0.05 \mathrm{M}$ Tris-buffered saline containing $0.05 \%$ Tween 20 (TBS-T), the nitrocellulose sheets were incubated overnight at $4^{\circ} \mathrm{C}$ with SP-A antibody (DAKO JAPAN Co., Ltd), diluted 1:500 with 0.05\% TBS-T. After $3 \times 10$ min wash, the blot was incubated for $1 \mathrm{~h}$ at room temperature with anti-mouse IgG antibody $(2 \mathrm{mg} / \mathrm{ml})$ diluted 1:1000 with $0.05 \%$ TBS-T (developed in goat, M-8642, Sigma Chemical Company, St. Louis, U.S.A.). After further $3 \times 10$ min wash, the blot was incubated with the secondary antibody, peroxidase-conjugated anti-goat IgG diluted 1:2000 with $0.05 \%$ TBS-T.

For SP-B and SP-D detection, rabbit polyclonal antisera to human lung SP-B and SP-D antibodies were used that were diluted 1:500 with $0.05 \%$ TBS-T. After further $3 \times 10$-min wash the blot was incubated for $1 \mathrm{~h}$ at room temperature with secondary antibodies. After the final wash with TBS, the blots were developed with a chemiluminescent detection system (ECL, Amersham, Life Science).

This work was carried out with approval of Human Ethic Institutional Commission.

\section{RESULTS}

Characterization of surfactant proteins in human organ of Corti, kidney and Eustachian tube lavage was performed by Western blotting after one-dimensional gel electrophoresis under reducing conditions by comparison with human lung BAL. Figure 1 shows the results obtained with an antibody directed against human pulmonary SP-B. This antibody strongly labelled the characteristic SP-B monomeric bands ( $8 \mathrm{kDa}$ ) in lung $\mathrm{BAL}$, organ of Corti, and Eustachian tube samples. Figure 2 shows the Western blot analyses of human Eustachian tube lavage that showed a strong $34 \mathrm{kDa}$ band for SP-A and $43 \mathrm{kDa}$ band

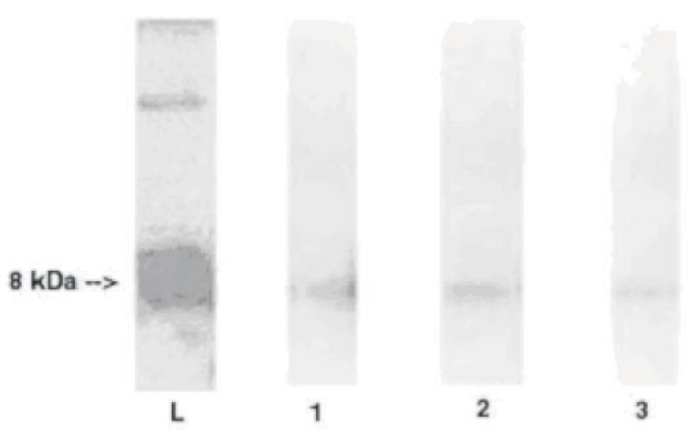

Figure 1. Detection of surfactant protein $B$ in the organ of Corti (lane 1), Eustachian tube (lane 2), kidney epithelium (lane 3).

Lane L represents positive control, e.g. SP-B detected in lung extract. Other explanations are within the text.

for SP-D. Characterization of SP-A and SP-D was also done in human kidney homogenate (Fig. 2B). Controls done in the presence of human BAL or in the absence of the first antibody were not labelled (not shown).

In the present study, SP-A, SP-B and SP-D were found to be strongly expressed in human ET, SP-B in human organ of Corti and SP-A and SP-D in kidney epithelium. This study produced the first evidence that human organ of Corti epithelium secrete SP-B. Expression of SP-A and SP-D by the kidney epithelium was also shown in this study. Additionally, the presence and distribution of SP-A, SP-B and SP-D in human Eustachian tube were also demonstrated. Surfactant proteins made in these tissues have the same molecular mass heterogeneity as the surfactant proteins found in the lungs.

Figures 1 and 2 show results obtained with mouse and rabbit antibodies against human surfactant proteins SP-A, SP-B and SP-D. For SP-B, it was interesting to detect it in ET and in the organ of Corti (Fig. 1), These tissue extracts all showed a SP-B positive band at 8 $\mathrm{kDa}$, the reported molecular mass of SP-B in the lung. The present study shows that SP-A 
and SP-D are present in kidney of human. Western blots of the human kidney extracts probed with antibodies against SP-A and SP-D each contained a single major band that corresponded to proteins with apparent moleculer masses of $34 \mathrm{kDa}$ and $86 \mathrm{kDa}$ (likely a SP-D dimer), respectively. On the other hand, we have observed two massess with the SP-A antibodies around $34 \mathrm{kDa}$ and $66 \mathrm{kDa}$ in the ET samples (Fig. 1). Previously, Kobayashi and co-workers (1992) reported the presence of a $80-\mathrm{kDa}$ protein in human middle ear samples. Likely, the PE-10 SP-A antibody cross-reacted with the human ET lavage proteins at $28-35 \mathrm{kDa}$ and $60-66 \mathrm{kDa}$. These two massess may be representing the monomer and dimer of SP-A respectively. Likely, the $66-\mathrm{kDa}$ band corresponds to nondisulfide-linked multimeric forms of SP-A, which are commonly reported for the lavage fluid and purified SP-A (Rubio et al., 1995) and cannot be reduced by 2-mercaptoethanol treatment. Kuroki et al. (1988) suggested that neither alkylation nor reduction plus alkylation completely prevented the formation of the 66-kDa form of SP-A in pulmonary tissue. Also, Fig. 2B shows that both surfactant proteins $\mathrm{A}$ and $\mathrm{D}$ were present in the kidney.

\section{DISCUSSION}

In the present study, evidence is given for the first time that hydrophilic surfactant pro- teins SP-A and SP-D characteristics for lungs are also expressed by kidney epithelium and SP-B by organ of Corti. These results bring new elements to the characterization of the surfactant material. Lamellar bodies are the storage and secretion form of surfactant in alveolar type II cells and have now been located in other human tissues (skin, joint, Eustachian tube, organ of Corti and kidney). Among these, only a few have been studied for the presence of surfactant proteins. SP-A has been detected in small intestine and colon (Rubio et al., 1995) and SP-D in stomach (Fisher \& Mason 1995). In the intestinal lumen, SP-A and SP-B have been shown to be associated with secreted surfactant-like particles (Eliakim et al., 1989; 1997).

The data outlined here provide new evidence that surfactant proteins are present in body sites other than lungs. Surfactant proteins in these tissues seem to be of possible clinical significance for diagnosis or treatment of a variety of disorders. The presence of SP-A and SP-D with SP-B within ET and SP-B in the human organ of Corti and SP-A and SP-D in kidney may be important for antibody-independent protection of these tissues. Both lung and these epidermal tissues are of endodermal origin. The known roles of surfactant proteins in pulmonary host defense, immunomodulation, and regulation of inflammatory cell activities indicate that surfactant proteins within the organ of Corti are likely to play a similar role in inflammatory and immunological disorders of the or-

A)
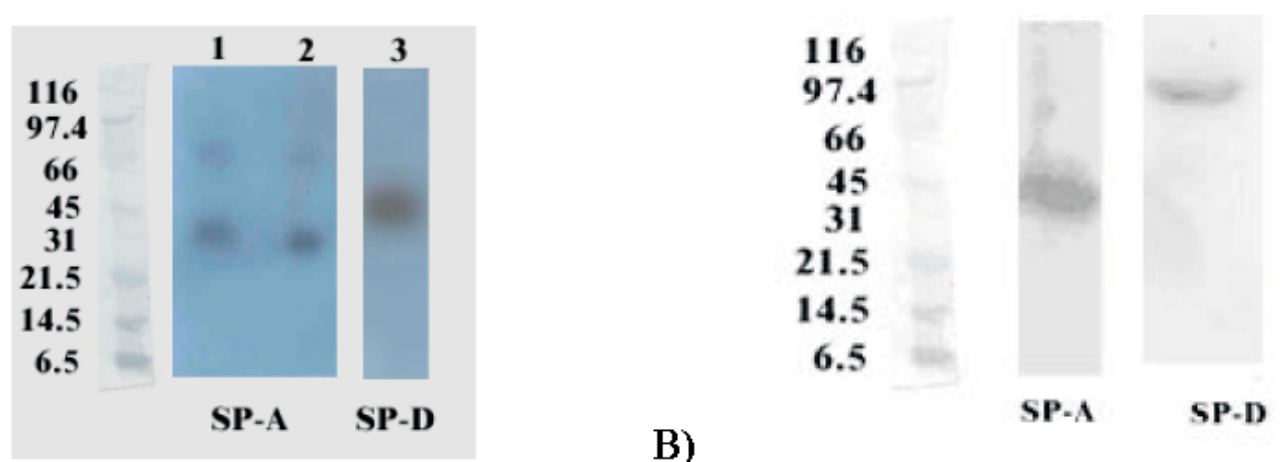

Figure 2. Immunodetection of SP-A and SP-D in Eustachian tube (A) and in kidney extract (B).

Other explanations are within the text. 
gan. This study also demonstrates the presence of surfactant proteins and their association with lamellar bodies in hairy cells of organ of Corti.

This study also provides the first evidence that human kidney epithelium secrete SP-A and SP-D. The expression of SP-A and SP-D in kidney tissues may be important role in the innate immunity. Previously, SP-D transcripts have been found in kidney (Motwani et al., 1995). Alcorn et al. (1992) previously showed that transformed green monkey kidney cells contain either the structural gene or cDNA for surfactant protein A (SP-A). Both SP-A and SP-D in kidney epithelium may have a role analogous to that in the lung. Previously, Paananen and co-workers (1999; 2001) described the expression of SP-A, SP-B and SP-D in the ET, suggesting that SP-A and SP-D play important roles in middle ear host defense and SP-B in normal opening of the tube and mucociliary transport. The presence of SP-B within the ET may suggest that SP-A, SP-B and SP-D affect hearing, vestibular function and immunity in the ear. Also, Ramet and co-workers (2001) concluded that SP-A is one of the surfactant proteins expressed in the Eustachian tube and its haplotypes and genotypes differ between children with recurrent middle ear inflammation (otitis media) compared with a control population. Therefore, a better description of the roles of surfactant proteins in the inner ear will provide new opportunities for pharmacotherapy of immune-mediated disorders of hearing and balance. Our study showed that SP-B is expressed in organ of Corti, which is a novel finding. However, it has been reported that cells within the organ of Corti synthesize phospholipids which is the major component of lung surfactant. Therefore, certain similarities to lung surfactant in phospholipids composition should be evaluated. In contrast with collectins, SP-B, a functionally crucial component of alveolar surfactant, seems to be present in the human organ of Corti so that, in the lung, SP-B and SP-A are implicated together in the formation of tubular myelin, the extracellular transition structure between lamellar body content and the surface lining film.

Kodama \& Asakura (1993) made the original suggestion that lung surfactant could be considered as an alternative treatment option for middle ear inflammation. Mira et al. (1997) concluded that any deficiency or altered production of tubal surfactant would significantly affect normal function of the ET and pre-dispose to pathological disorders such as inflammation of middle ear.

SP-A and SP-D play distinct roles during bacterial, viral and fungal infections of the lung. LeVine et al. (2000) demonstrated that SP-D and SP-A play roles in modulating cytokine production and inflammatory responses during bacterial pneumonia (Streptococcus pneumonia). Streptococcal pneumonia is one of the causative agents of middle ear inflammation and causes changes occuring in a defined sequence; i.e., damage to the supporting cells, changes in stereocilia, and, finally, hair cell loss (Hodges et al., 1984). These findings suggest that surfactant proteins may be important in combating infections at sites other than the lung. Further studies will be necessary to characterize the function of surfactant proteins in extra-alveolar sites.

The antibody used in Western blotting was monoclonal SP-A antibody (PE-10). It has been shown that both SP-A1 and SP-A2 genes contain the nucleotide sequence corresponding to the peptides that react with monoclonal SP-A antibody (Katyal et al., 1992; Murata et al., 1993; Hiraike et al., 1995). Therefore, PE-10 is able to detect both SP-A1 and SP-A2 equally well. It is therefore safe to conclude that the localization and synthesis of surfactant proteins is not restricted to the respiratory system.

Deficiencies of the surfactant proteins may predispose to infections or other complications, e.g., reperfusion injuries or autoimmune diseases in lungs. Furthermore, to analyse expression of surfactant proteins in disease will be extremely interesting and may have potential for clinical application for the 
investigation of pathogenesis of diseases in the examined tissues.

Professor David Williams, John Tonge Centre is acknowledged for providing Eustachian tube, organ of Corti and kidney samples.

\section{R E F E R E N C E S}

Alcorn JL, Chen Q, Boggaram V, Mendelson CR. (1992) Expression and transport of rabbit surfactant protein A in COS-1 cells. Am $J$ Physiol.; 262: L437-45.

Billis A. (1994) Bladder malacoplakia in a patient on chronic hemodialysis waiting for kidney transplantation. Nephron.; 67: 127-38.

Chailley-Heu B, Rubio S, Rougier JP, Ducroc R, Barlier-Mur AM, Ronco P, Bourbon JR. (1997) Expression of hydrophilic surfactant proteins by mesentery cells in rat and man. Biochem J.; 328: 251-6.

Eliakim R, Deschryver-Kecskemeti K, Nogee L, Stenson WF, Alpers DH. (1989) Isolation and characterization of a small intestinal surfactant-like particle containing alkaline phosphatase and other digestive enzymes. $J$ Biol Chem.; 264: 20614-9.

Eliakim R, Goetz GS, Rubio S, Chailley-Heu B, Shao JS, Ducroc R, Alpers DH. (1997) Isolation and characterization of surfactant-like particles in rat and human colon. Am J Physiol.; 272: G425-34.

Fisher JH, Emrie PA, Shannon J, Sano K, Hattler B, Mason RJ. (1988) Rat pulmonary surfactant protein A is expressed as two differently sized mRNA species which arise from differential polyadenylation of one transcript. Biochim Biophys Acta.; 950: 338-45.

Fisher JH, Mason RJ. (1995) Expression of pulmonary surfactant protein $\mathrm{D}$ in rat gastric mucosa. Am J Respir Cell Mol Biol.; 12: 13-8.

Glasser SW, Korfhagen TR, Weaver T, Pilot-Matias T, Fox JL, Whitsett JA. (1987) cDNA and deduced amino acid sequence of human pulmonary surfactant-associated proteolipid SPL (Phe). Proc Natl Acad Sci U S A.; 84: 4007-11.

Haagsman HP, Sargeant T, Hauschka PV, Benson BJ, Hawgood S. (1990). Binding of calcium to SP-A, a surfactant-associated protein. Biochemistry.; 29: 8894-900.

Harada Y, Sakai T, Tagashira N, Suzuki M. (1986) Intracellular structure of the outer hair cell of the organ of Corti. Scan Electron Microsc.; 2: 531-5.

Hiraike N, Sohma H, Kuroki Y, Akino T. (1995) Epitope mapping for monoclonal antibody against human surfactant protein A (SP-A) that alters receptor binding of SP-A and the SP-A-dependent regulation of phospholipid secretion by alveolar type II cells. Biochim Biophys Acta.; 1257: 214-22.

Hodges KB, Penny JE, Brown RD, Henley CM. (1984) Scanning electron microscopy of the cochlea in rats with Streptococcus pneumoniae otitis media. Arch Otolaryngol.; 110: 429-36.

King RJ, Klass DJ, Gikas EG, Clements JA. (1973) Isolation of apoproteins from canine surface active material. Am $J$ Physiol.; 224: 788-95.

Kobayashi K, Yamanaka N, Kataura A, Ohtani S, Saito T, Akino T. (1992) Presence of an 80 kilodalton protein, cross-reacted with monoclonal antibodies to pulmonary surfactant protein A, in the human middle ear. Ann Otol Rhinol Laryngol.; 101: 491-5.

Kodama H, Asakura K. (1993) Role of surface tension lowering substances in the function of normal and diseased eustachian tubes of guinea pigs. Nippon Jibiinkoka Gakkai Kaiho.; 96: 674-84.

Kuroki Y, Mason RJ, Voelker DR. (1988) Alveolar type II cells express a high-affinity receptor for pulmonary surfactant protein A. Proc Natl Acad Sci U S A.; 85: 5566-70.

Laemmli UK. (1970) Cleavage of structural proteins during the assembly of the head of bacteriophage T4. Nature.; 227: 680-5.

LeVine AM, Whitsett JA, Gwozdz JA, Richardson TR, Fisher JH, Burhans MS, Korfhagen TR. (2000) Distinct effects of surfactant pro- 
tein A or D deficiency during bacterial infection on the lung. Immunol.; 165: 3934-40.

Liau DF, Ryan SF. (1991) Purification of surfactant protein A from dog lung by reconstitution with surfactant lipids. Chem Phys Lipids.; 59: 29-38.

Lu J, Willis AC, Reid KB. (1992) Purification, characterization and cDNA cloning of human lung surfactant protein D. Biochem J.; 284: 795-802.

Mira E, Benazzo M, De Paoli F, Casasco A, Calligaro A. (1997) Surfactants of the airways. Critical review and personal research. Acta Otorhinolaryngol Ital.; 17: 3-16.

Motwani M, White RA, Guo N, Dowler LL, Tauber AI, Sastry KN. (1995) Mouse surfactant protein-D. cDNA cloning, characterization, and gene localization to chromosome 14. J Immunol.; 155: 5671-7.

Murata Y, Kuroki Y, Akino T. (1993) Role of the C-terminal domain of pulmonary surfactant protein A in binding to alveolar type II cells and regulation of phospholipid secretion. Biochem J.; 291: 71-6.

Ormos J. (1995) Concentric lamellar bodies in renal basement membranes. Ultrastruct Pathol.; 19: 515-7.
Paananen R, Glumoff V, Hallman M. (1999) Surfactant protein A and D expression in the porcine Eustachian tube. FEBS Lett.; 452: 141-4.

Paananen R, Glumoff V, Sormunen R, Voorhout W, Hallman M. (2001) Expression and localization of lung surfactant protein B in Eustachian tube epithelium. Am J Physiol Lung Cell Mol Physiol.; 280: L214-20.

Ramet M, Lofgren J, Alho OP, Hallman M. (2001) Surfactant protein-A gene locus associated with recurrent otitis media. $J$ Pediatr.; 138: $266-8$.

Rubio S, Lacaze-Masmonteil T, Chailley-Heu B, Kahn A, Bourbon JR, Ducroc R. (1995) Pulmonary surfactant protein A (SP-A) is expressed by epithelial cells of small and large intestine. J Biol Chem.; 270: 12162-9.

Taneva SG, Keough KM. (2000) Differential effects of surfactant protein A on regional organization of phospholipid monolayers containing surfactant protein B or C. Biophys J.; 79: $2010-3$.

Vamvakopoulos NC, Modi WS, Floros J. (1995) Mapping the human pulmonary surfactant-associated protein B gene (SFTP3) to chromosome 2p12->p11.2. Cytogenet Cell Genet.; 68: 8-10. 